\title{
PILOT SCALE INTEGRATED ANAEROBIC-AEROBIC TREATMENT OF PALM OIL MILL EFFLUENT
}

\author{
MUZZAMMIL, $\mathbf{N}^{\star}$ and LOH, S K${ }^{*}$
}

\begin{abstract}
Palm oil mill effluent (POME) is abundantly generated from the palm oil milling process. Its stringent discharge limits of biological oxygen demand (BOD) of $<20 \mathrm{mg} \mathrm{litre}^{-1}$ has been the most prevalent issue faced in the course of extending palm oil business development. Conventional POME treatment system anaerobically in a series of ponding systems, topped with additional costly tertiary polishing system may not be able to meet this challenging standard due to inconsistent plant performance. A cost-effective POME treatment technology featuring full resource recovery and zero discharge/zero emissions is encouraged. This article examined the performance of an integrated anaerobic-aerobic zero discharge POME treatment pilot system in full operation for a year in a palm oil mill. The assessed system showed $100 \%$ compliance to BOD of $100 \mathrm{mg} \mathrm{litre}^{-1}$ and $80 \%$ for the more stringent BOD $20 \mathrm{mg} \mathrm{litre}^{-1}$ while generating renewable electricity from the combusted biogas and recycling boiler-grade water via reclamation.
\end{abstract}

Keywords: palm oil, wastewater, biological oxygen demand, biogas, anaerobic-aerobic.

Date received: 19 February 2019; Sent for revision: 20 February 2019; Accepted: 19 June 2019.

\section{INTRODUCTION}

Palm oil mill effluent (POME) has always attracted interest of various stakeholders. It is still being extensively studied for possible exploitation in many areas. Currently, it is a focus of the industry to use it for bioenergy application besides a lot of discussion on POME being held in relation to its environmental concern (Kushairi et al., 2018). POME in its physical form is a thick brownish liquid wastewater, acidic in nature, high in colloidal suspension and has an unpleasant odour (Loh et al., 2013; Liew et al., 2015). It is a combined wastewater from three main milling activities: sterilisation, oil/sludge clarification and hydrocyclone (60:35:5) (Liew et al., 2015). Other minor wastewater streams include turbine cooling water, boiler blowdown water, overflows from vacuum dryer and floor washings; the volumes of which are largely dependent on mill policies

\footnotetext{
Malaysian Palm Oil Board,

6 Persiaran Institusi, Bandar Baru Bangi,

43000 Kajang, Selangor, Malaysia.

E-mail: lohsk@mpob.gov.my
}

and operations. The final combined wastewater (in its raw stage) is essentially composed of 95\%96\% water, $4 \%-5 \%$ total organic solids (including dissolved organic nutrients, complex sugars and plant proteins), $0.6 \%-0.7 \%$ oil, grease and traces of other organic components (Ma, 2000; Ahmad et al., 2003).

POME is typically high in biological oxygen demand (BOD) of $\sim 25000 \mathrm{mg}$ litre $^{-1}$ and chemical oxygen demand (COD) of $~ 50000 \mathrm{mg} \mathrm{litre}^{-1}$ (Loh et al., 2013). It is traditionally treated via anaerobic and aerobic digestion in large open lagoons. More recently, biogas plants have been installed and integrated with the ponding system to optimise anaerobic digestion of POME under a controlled manner (Loh et al., 2017; 2013; 2011; Hosseini et al., 2013; Basri et al., 2010; Yacob et al., 2006). Such integration can achieve a BOD and COD reduction of $>90 \%$ to $<500 \mathrm{mg}$ litre $^{-1}$ (Loh et al., 2013; 2011). However, the major challenge remains to further reducing the BOD to below $20 \mathrm{mg}^{\text {litre }}{ }^{-1}$ discharge standards as enforced by the Department of Environment (DOE), Malaysia. The final BOD reduction via aerobic digestion is influenced by 
bacterial activity, inconsistent incoming BOD/ COD value, rainwater and concentration of present oxygen. A further issue lies within the difficulty in recycling bacteria to avoid constant replenishment of new bacteria, as a cost-saving measure, prior to discharging the effluent for land irrigation.

To overcome difficulties in managing aerobic bacterial activity, other more effective approaches such as decanting, flocculating and filtering the final suspended solids (SS) of POME are attempted to meet BOD discharge compliance (Liew et al., 2015; Azmi and Yunos, 2014), without much success. Apart from high capital cost involved for membranebased filtering system, the colloidal suspension and dissolved plant proteins and sugars present in POME cannot be removed. In particular, organic fouling of POME can pose significant problem to the membrane or nano filtration systems used. The complexity of POME characteristics has caused the industry in deep frustration in searching for reliable technology to consistently meet stricter BOD standards.

To solve the above, most of the recent studies have looked into the possibility of reducing POME during the palm oil milling process or maximising POME utilisation and recovery aiming at zero discharge or zero emissions. Previously, a zero discharge pilot plant study incorporating the anaerobic, aerobic and reclamation system (reverse osmosis and ultrafiltration) was proven able to treat POME to a highly clean water that can be recycled and reused as boiler feed water, thus achieving zero discharge (Loh et al., 2013; Tabassum et al., 2015). Besides, combined treatment of activated carbon followed by a chemical coagulant has been found effective in reducing the concentration of SS and COD from POME to below the limit set for final discharge (Othman et al., 2014), thus fulfilling the zero emissions concept. The disposal of POME via evaporation has long been attempted (Ma, 1999), and recently revisited involving reduction of effluent production followed by continued composting (Rahman et al., 2013) and during palm oil clarification involving 2-phase decanter and multiple-effect evaporator (Kandiah and Batumalai, 2013). During evaporation (vaporisation or 'boiling') of wastewater-containing water, high temperature and flow rate are applied to overcome the liquid-gas phase intermolecular forces to allow for escape of water molecules from the liquid into the air.

Several innovative approaches - often involving combination of several individual technologies - in handling POME to meet stringent discharge standards have been researched. To date, the industry has still constantly encountered environmental allegations in the course of pursuing sustainable POME management via various means. Although much has been discussed on dealing with POME towards zero discharge, information on its techno-economic viability and practicality is lacking to convince millers for commercial adoption, in particular, on biogas production and BOD reduction potential judging on the high incurred cost. Our previous study (Loh et al., 2013) has demonstrated that zero discharge POME treatment system installed at a typical (60 $\mathrm{thr}^{-1}$ fresh fruit bunch) palm oil mill can be economically feasible based on 10 hr operation over a 12-month period. Continuing thereafter, its performance based on $24 \mathrm{hr}$ operation representing commercial operation was established. The plant's integrated anaerobic-aerobic microbial conditions were adjusted to tackle some of the issues and challenges encountered and further improved under this operation mode. With the collection of data from this study together with the previous study mentioned above, the industry will be furnished with relevant and practical scientific information in the aspects of operating a zero discharge POME treatment process. This is done bearing in mind that the main targets are to achieve highest compliancy to BOD 20 regulation as well as demonstrating a practical performance of a POME zero discharge treatment system with biogas system supporting the entire plant with the target of achieving $30 \mathrm{~m}^{3} \mathrm{~m}^{-3}$ of POME.

\section{MATERIALS AND METHODS}

\section{Integrated Anaerobic-aerobic POME Treatment Pilot Plant}

The plant was completed in 2011 with the objective to demonstrate a total zero discharge POME treatment technology (Loh et al., 2013). It is located in the compound of the Palm Oil Milling Technology Centre (POMTEC) which is an actual mill run in collaboration with Sime Darby Plantation Sdn Bhd with $20 \mathrm{t} \mathrm{hr}^{-1}$ capacity receiving $100 \%$ of its fresh fruit bunch from its own plantation. A total of $5 \mathrm{~m}^{3}$ of POME from POMTEC was fed into the integrated system comprising pre-treatment, anaerobic and aerobic digestion and biogas production (Figure 1). The POMTEC monitoring of plant performance covered BOD of aerobically treated POME and biogas production (volume) after anaerobic digestion of POME. Other POME characteristics at $24 \mathrm{hr}$ operation for a year were briefly discussed.

Pre-treatment involved: (i) removal of loose unwanted materials such as stones, sands, grass, sticks, etc. using grit screen, (ii) oil removal via clarification using oil separation tank, (iii) stabilisation through retention of POME in an equalisation tank, and finally (iv) $\mathrm{pH}$ correction using $\mathrm{NaOH}$ at dosing tank. Two modular mesophilic reactors $\left(\mathrm{AnaEG}^{\circledR}\right)$ modified from expanded granular sludge bed (EGSB) concept were used for anaerobic digestion of POME after 
pre-treatment step. The tanks have an effective capacity of $400 \mathrm{~m}^{3}$ each and are run in parallel with an estimated hydraulic retention time (HRT) of seven days for a $5 \mathrm{~m}^{3}$ hourly influent. Two main outputs from the anaerobic tanks were biogas and treated effluent. The generated biogas was passed through a biogas purifier containing ferric chloride to scrub and reduce the hydrogen sulphide $\left(\mathrm{H}_{2} \mathrm{~S}\right)$ content. The treated effluent from the anaerobic tank was passed through a dissolved air floatation (DAF) system where tiny bubbles were generated from the dissolved air in the effluent under pressure which were then released at atmospheric pressure in a floatation basin. The bubbles would then capture the SS on their way to the surface of the basin. This created a layer of floating solids or froth which then would be skimmed and removed. The dosed coagulant into this system clustered the SS for better attachment with the bubbles. Then, the aerobic digestion process took place using the attached growth aerobic treatment method in a BioAX ${ }^{\circledR}$ reactor. A uniquely designed media was used for bacteria attachment and formation of biofilm.
The biofilm was continuously exposed to the air and treated effluent to allow for effective aerobic digestion of POME.

\section{Scope of Monitoring}

The plant was assessed from June 2012 to June 2013 on a $24 \mathrm{hr}$ basis except from January 2013 onwards, on a $9 \mathrm{hr}$ basis due to insufficient crops for processing leading to a reduced feeding of POME from the intake point, i.e. cooling pond. The sampling points of POME were as specified (Figure 2). Four POME sampling points were identified: influent of equalisation tank, P1; influent of $\mathrm{AnaEG}^{\circledR}$ tank, P2; effluent of AnaEG $^{\circledR}$ tank, P3 and effluent of BioAx ${ }^{\circledR}$, P4. POME quality analyses were carried out weekly according to the DOE approved method (DOE, 1995) to determine the reduction of BOD and COD as well as other parameters. The compositions of treated biogas $\left(\mathrm{CH}_{4}, \mathrm{CO}_{2}\right.$ and $\left.\mathrm{H}_{2} \mathrm{~S}\right)$ were recorded using an on-site biogas analyser - Biogas 401 (ADOS GmbH) installed at the outlet of biogas scrubber, G2 (Figure 2). Similar measurement was done on the raw biogas

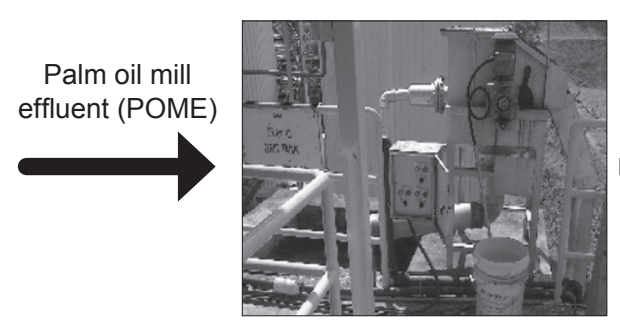

Grit screen

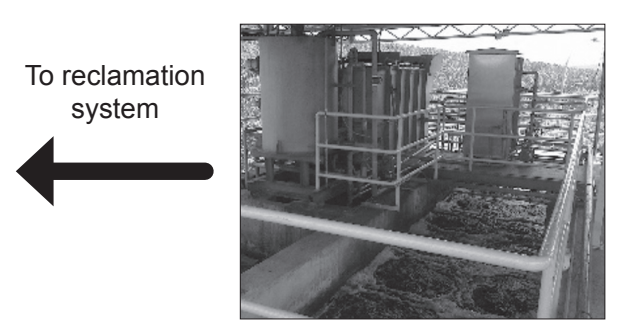

BioAX ${ }^{\circledR}$

(anaerobic treatment)

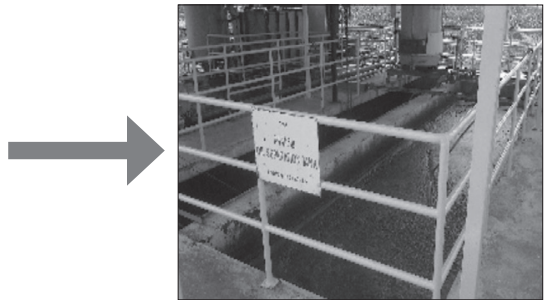

Oil separation and equalisation tank
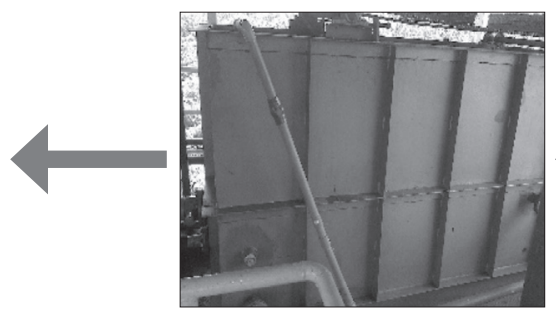

Dissolved air floatation

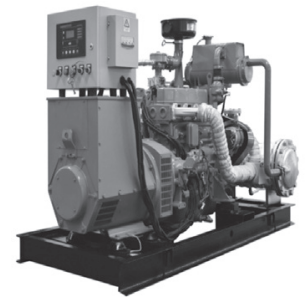

Biogas engine for electricity generation

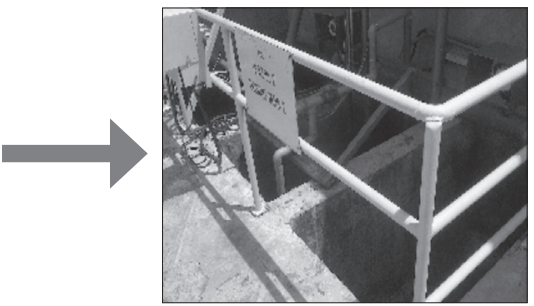

Dosing tank

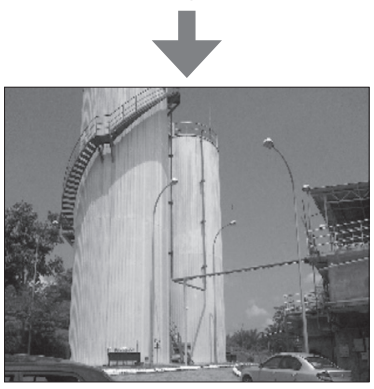

AnaEG ${ }^{\circledR}$ tanks (anaerobic treatment)

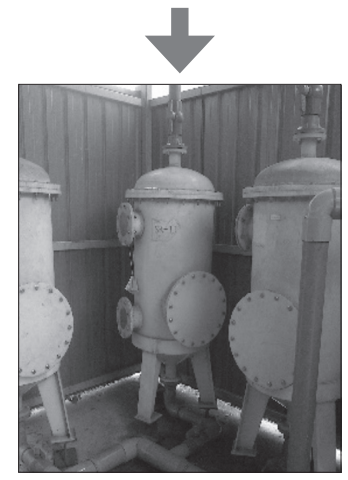

Biogas scrubber system

Figure 1. Process flow of palm oil mill effluent (POME) pre-treatment, anaerobic/aerobic digestion and biogas to electricity generation. 


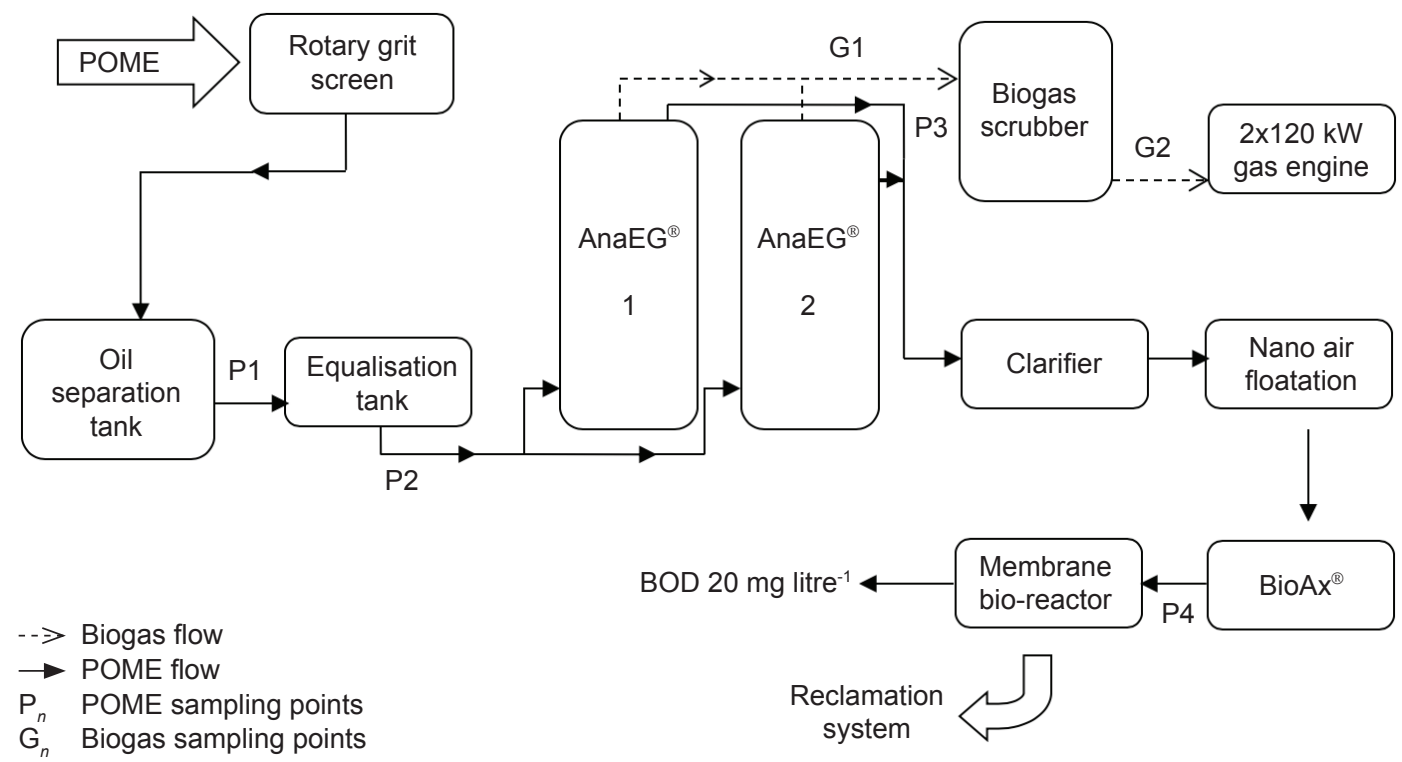

Figure 2. Location of palm oil mill effluent (POME) and biogas sampling points.

produced from AnaEG ${ }^{\circledR}$ tank at G1 (Figure 2) using a mobile gas analyser, MRU Vario Plus Industrial. The reduction of $\mathrm{H}_{2} \mathrm{~S}$ in biogas was then estimated based on the difference in $\mathrm{H}_{2} \mathrm{~S}$ concentration before and after scrubbing. The volume of biogas production $\left(\mathrm{m}^{3}\right)$ was calculated based on Equation (1) which was adapted from Chernicharo (2007). The biogas monitoring was conducted for three months from January 2013 to March 2013. Close monitoring was focused on achieving BOD $<20 \mathrm{mg}$ litre $^{-1}$ at $\mathrm{P} 4$ (Figure 2) and biogas production of $30 \mathrm{~m}^{3} \mathrm{~m}^{-3}$ of POME at G1.

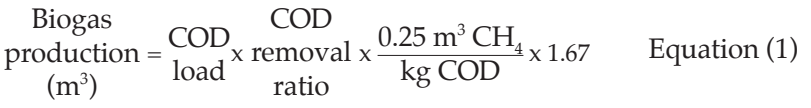

where COD is the chemical oxygen demand of POME, and 1.67 is the simplified value to represent the assumption of $60 \%$ methane composition in a volume of biogas.

\section{RESULTS AND DISCUSSION}

\section{Biogas Production}

The performance of AnaEG ${ }^{\circledR}$ anaerobic digesters is closely linked up with the COD reduction efficiency. Overall, the AnaEG digesters were capable of producing an average of $28.98 \mathrm{~m}^{3}$ of biogas $\mathrm{m}^{-3}$ of POME fed into the system (Figure 3). This is very much similar to the theoretical value of $28 \mathrm{~m}^{3}$ of biogas $\mathrm{m}^{-3}$ of POME as reported in the pioneering study on biogas from POME (Ma et al., 1994). It is also in the range of biogas production rate reported by other technologies (Table 1) (Loh et al., 2017). There were several occasions where the feeding of raw POME into the plant was disrupted which had subsequently affected the biogas production. For example in August 2012, the plant experienced a significant increased amount of oil in the feeding POME from an averaged $94 \mathrm{mg}$ litre $^{-1}$ to $>300 \mathrm{mg}$ litre $^{-1}$. The oil separation tank (Figure $4 a$ ) was unable to accommodate this surge which then caused direct carryover to the equalisation tank (Figure $4 b$ ) and subsequent flow to the anaerobic digesters. Several researchers reported that significant amount of oil content causes sludge flotation, foaming in digester and long-chain fatty acid toxicity effect on methanogenic bacteria (Alves et al., 2001; Jeganathan et al., 2006; Ganidi et al., 2009;) that could hinder the production of biogas. Similar effect occurred in this study and was reflected in biogas production trend (Figure 3) with significant drop in September 2012 and spill over into the following two months. Another problem was consistent plant performance caused by quantity of POME. A lesser amount of raw POME was received from April 2013 onwards where feeding was done for three days only in a week, so the system encountered difficulty in maintaining an effective POME working volume as well as consistent temperature required in each treatment process. Subsequently, microbial activity in the digesters was reduced under this undesirable working environment. The impact of this condition was reflected by a drop of biogas volume to its lowest at $22 \mathrm{~m}^{3} \mathrm{~m}^{-3}$ of POME towards the end of plant monitoring period from May to June 2013 (Figure 3). Maintaining correct operating conditions is vital in ensuring the performance and capability of the digesters. It was evident that the 


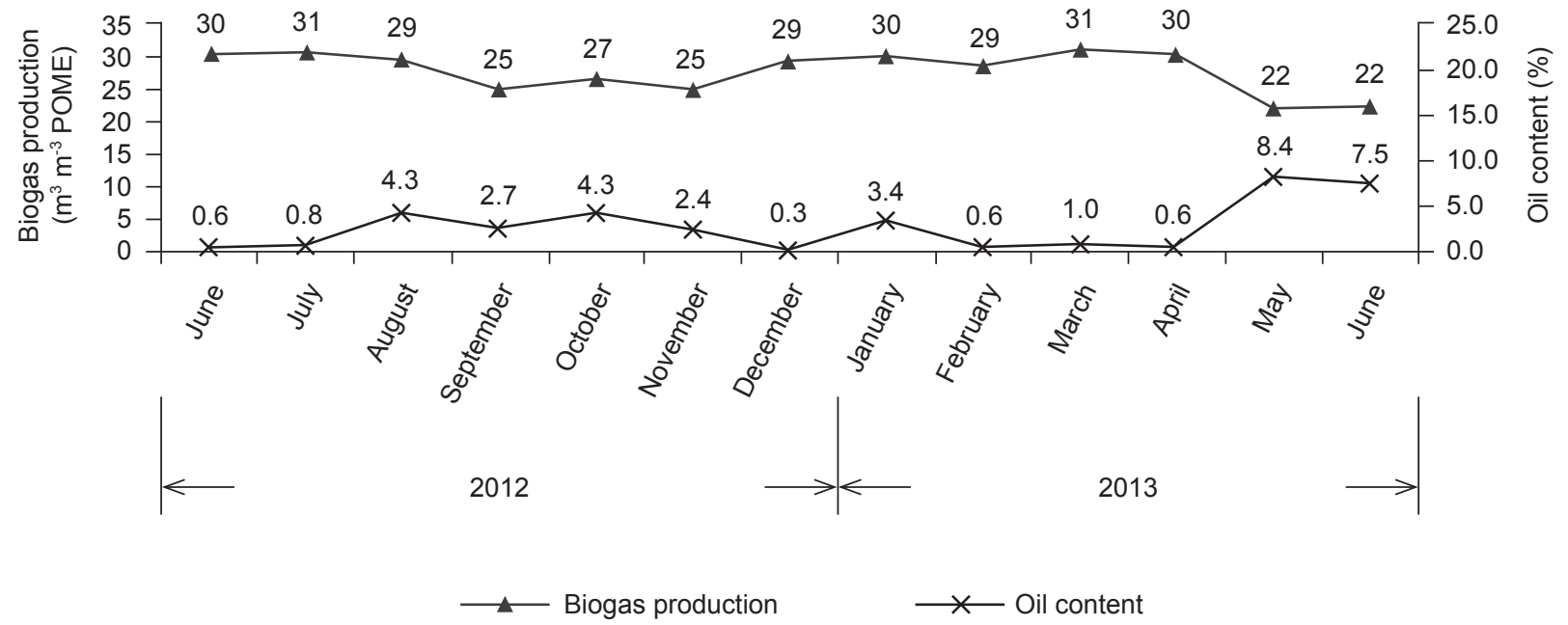

Note: From the graph, the increased of oil content has significantly reduced the biogas production.

Figure 3. Calculated biogas production from palm oil mill effluent (POME) throughout the monitoring period (June 2012-June 2013).

TABLE 1. COMPARISON OF BIOGAS PRODUCTION RATE BY SEVERAL SELECTED BIOGAS TECHNOLOGIES IN MALAYSIA

\begin{tabular}{lccc}
\hline \multicolumn{1}{c}{ Technology } & $\begin{array}{c}\text { Working temperature } \\
\left({ }^{\circ} \mathbf{C}\right)\end{array}$ & $\begin{array}{c}\text { Hydraulic retention time } \\
(\text { day })\end{array}$ & $\begin{array}{c}\text { Biogas production rate } \\
\left(\mathbf{m}^{3} \mathbf{t}^{-1} \mathbf{P O M E}\right)\end{array}$ \\
\hline Continuous-flow stirred tank reactor & $35-42$ & $14-18$ & $24-32$ \\
High efficiency fermentation tank & $31-32$ & 9 & $26-30$ \\
Covered lagoon & - & 27 & 25 \\
Covered high energy anaerobic pond & $38-40$ & 30 & 30 \\
AnaEGTM & $35-38$ & 9 & 29 \\
\hline
\end{tabular}

performance of anaerobic digesters in this study was hampered by sudden increase of oil content in the POME, leading to $\simeq 20 \%$ reduction in biogas production. Continuous feeding of POME to the digesters must also be ensured to avoid abrupt changes in $\mathrm{pH}$ and temperature during anaerobic digestion.

\section{Biogas Compositions}

The purified biogas comprised an average of $58.3 \%$ (v/v) of $\mathrm{CH}_{4} 41.8 \%$ (v/v) of $\mathrm{CO}_{2}$ and 446 $\mathrm{mg}$ litre $^{-1}$ of $\mathrm{H}_{2} \mathrm{~S}$ (Figure 5). Throughout the threemonth monitoring, the methane composition was maintained above 53\% with its maximum at $65 \%$ indicating a healthy anaerobic degradation process of POME for the digesters. However, the concentration of $\mathrm{H}_{2} \mathrm{~S}$ indicated that the biogas produced requiring further treatment to meet the threshold of $<200 \mathrm{mg} \mathrm{litre}^{-1}$ for combustion in the biogas engines. Though scrubbing of biogas using ferric oxide had significantly reduced about $80 \%$ of the originally over $2000 \mathrm{mg} \mathrm{litre}^{-1} \mathrm{H}_{2} \mathrm{~S}$ (Figure 5) concentration generated, it was still inadequate in this case to reach the allowable $\mathrm{H}_{2} \mathrm{~S}$ limit for an efficient gas engine operation.

\section{POME Treatment}

In total, throughout the assessment period, 78 sets of POME sample from the outlet of BioAx ${ }^{\circledR}$, P4 (Figure 2) were analysed. Overall, $80.8 \%$ of the POME samples recorded BOD $<20 \mathrm{mg}^{\text {litre }}{ }^{-1}$ (Figure 6), $97.4 \%$ for BOD $<50 \mathrm{mg}^{\text {litre }}{ }^{-1}$ and $100 \%$ for BOD $<100 \mathrm{mg}$ litre $^{-1}$. The plant had also significantly reduced the averaged BOD from 12576 to $49 \mathrm{mg}$ litre $^{-1}$, COD from 64761 to $494 \mathrm{mg} \mathrm{litre}^{-1}$ and total solids from 46307 to $3880 \mathrm{mg}^{\text {litre }}{ }^{-1}$ of the incoming POME reaching 99.6\%, $98.93 \%$ and $91.61 \%$ reduction, respectively (Figure 7). The quality of treated POME at this point (P4) aligned well with the specific requirement for subsequent water reclamation system to produce recycled water (Loh et al., 2013). As the plant was an integrated anaerobic $\left(\right.$ AnaEG $\left.^{\circledast}\right)$-aerobic $\left(B{ }^{\infty} A x^{\circledast}\right)$ system, the sudden increase of oil content, temperature drop as well as the reduction in raw POME feed had also affected the BOD reduction potential of the plant (Figure 6) especially in August 2012, May 2013 and June 2013. The sudden surge of oil content can be seen affecting the BOD reading at point $\mathrm{P} 4$ as reflected in Figure 6. POME samples were not taken during these abnormal operation periods. 
Currently, majority of palm oil mills in Peninsular Malaysia are licensed with BOD of 100 $\mathrm{mg}$ litre $^{-1}$ for final discharge of POME. The integrated anaerobic-aerobic POME treatment plant in this study has no problem in complying with the current BOD limit set. For an anticipated stricter regulation of BOD limit in the future, the plant has also proven its ability to consistently reach BOD below $50 \mathrm{mg}$ litre $^{-1}$ as early as in its aerobic treatment stage before polishing further as final discharge into a waterway.
The lower BOD profile obtained at aerobic stage also is desirable for water reclamation through the use of membrane bioreactor, ultrafiltration and reverse osmosis aiming at a zero POME discharge in palm oil milling. However, for more stringent BOD 20 mg litre ${ }^{-1}$ compliance, the plant must be upgraded to tackle the remaining solids in the effluent as they contribute significantly to BOD. One of the areas worth further pursuing is to optimise bubble size during DAF treatment for maximum attachment of

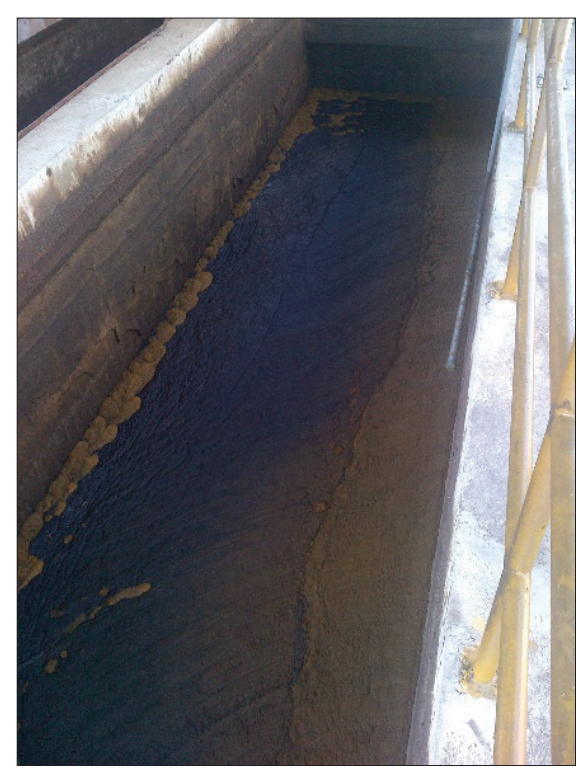

(a)

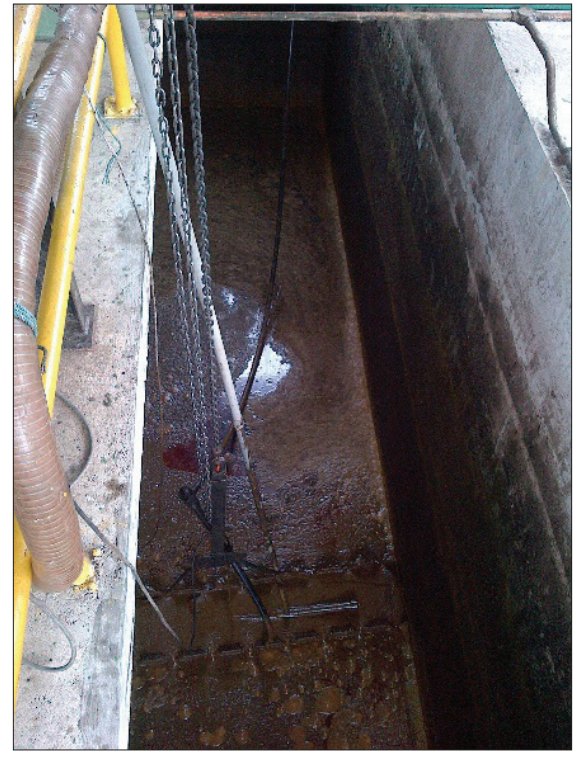

(b)

Figure 4. Thick layer of oil formed on the surface of (a) oil separation tank and (b) equalisation tank.

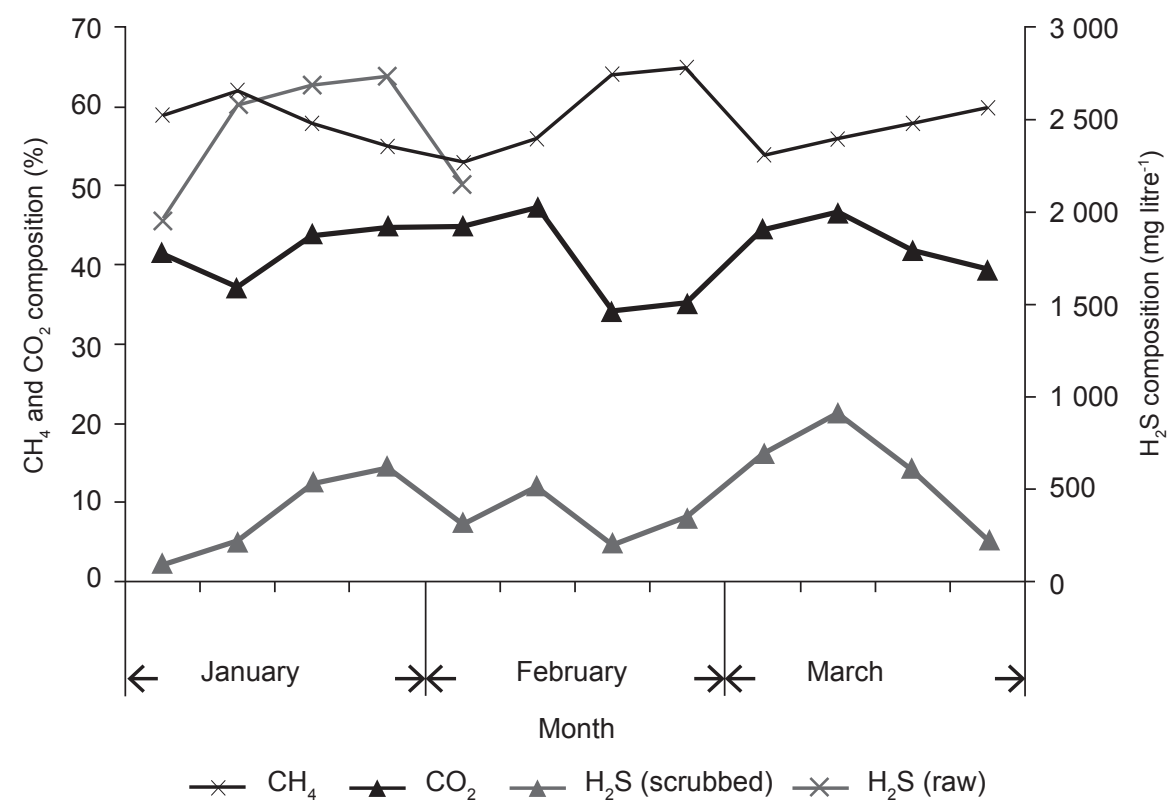

Note: $\mathrm{CH}_{4}$ - methane, $\mathrm{CO}_{2}$ - carbon dioxide, $\mathrm{H}_{2} \mathrm{~S}$ - hydrogen sulphide.

The composition of $\mathrm{H}_{2} \mathrm{~S}$ (raw) was measured for five weeks only.

Figure 5. A three-month monitoring of biogas compositions $\left(\mathrm{CH}_{4^{\prime}} \mathrm{CO}_{2}\right.$ and $\left.\mathrm{H}_{2} \mathrm{~S}\right)$ from sampling point of G1 (raw) and G2 (scrubbed). 


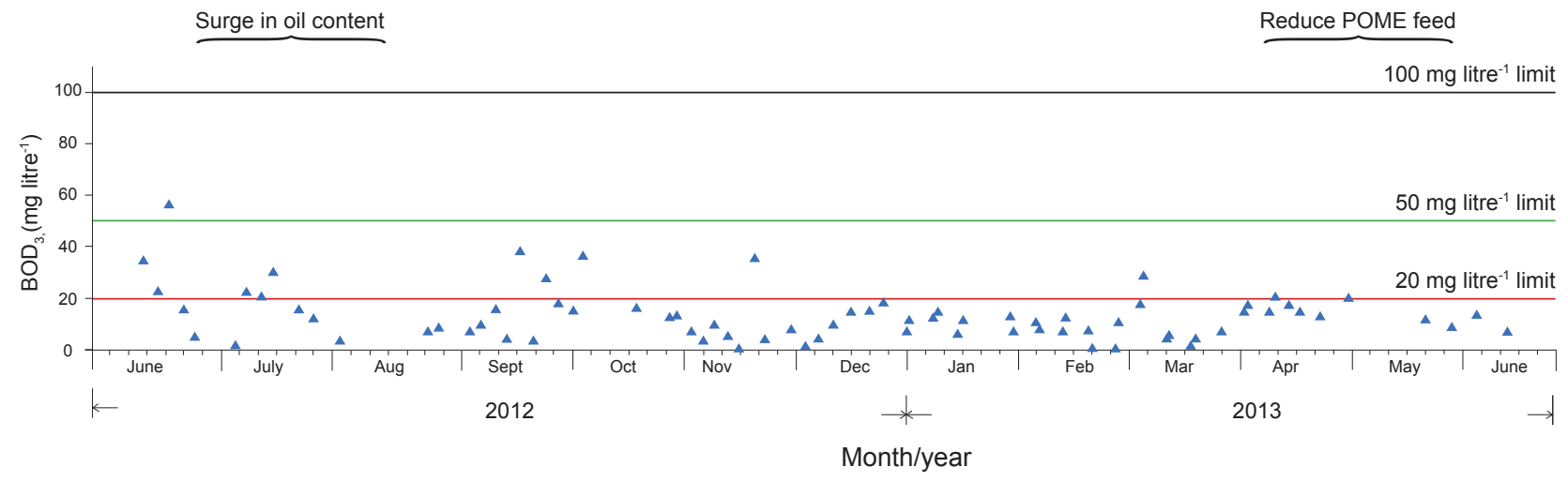

Figure 6. The perfomance consistency of palm oil mill effluent (POME) in achieving <20 mg litre-1 biological oxygen demand (BOD) throughout the monitoring period (June 2012-June 2013).

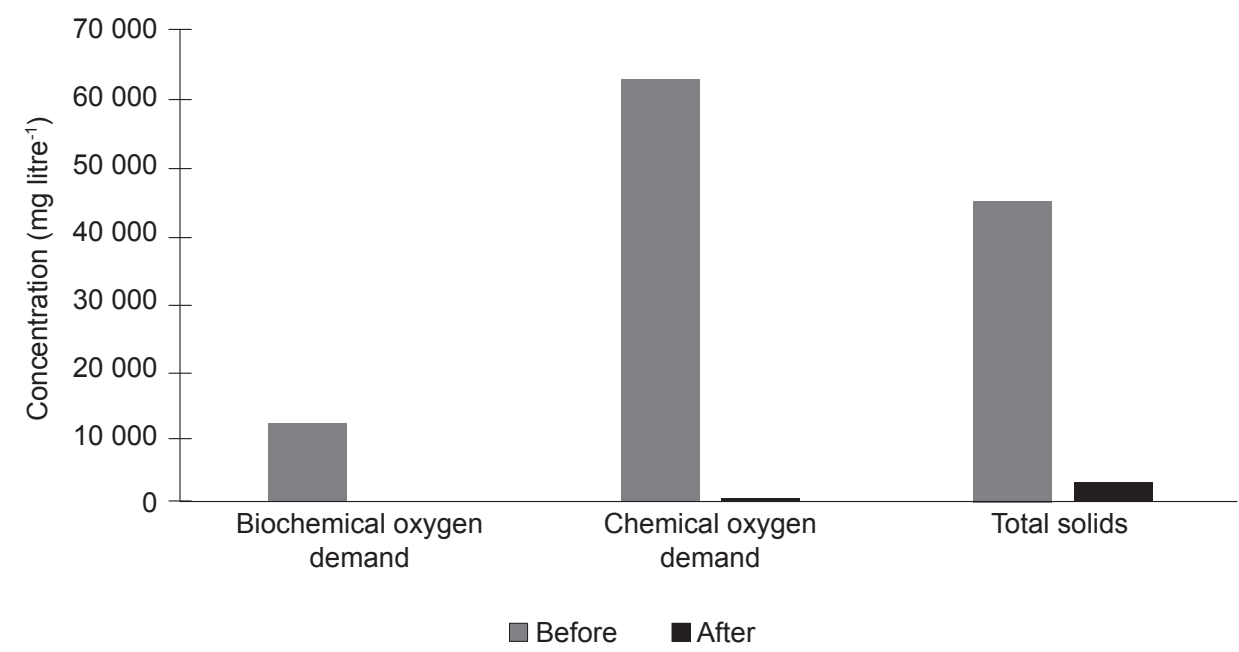

Figure 7. Reduction of main quality parameters of palm oil mill effluent (POME) during anaerobic digestion at sampling point (P4).

the remaining SS. The design of the DAF tank can be modified and improved to provide adequate time for close contact between the bubbles and the SS.

\section{CONCLUSION}

The integrated anaerobic-aerobic POME treatment plant was capable of achieving $>80 \%$ consistency with regards to BOD limit of $20 \mathrm{mg}^{\text {litre }}{ }^{-1}$ for the treated POME. Its overall performance for other POME parameters was of satisfactory quality too. Its ability to produce biogas was high at $\sim 30 \mathrm{~m}^{3} \mathrm{~m}^{-3}$ of POME. Besides, its good performance characteristics and the properly maintained process parameters at each treatment stage also had supported the subsequent downstream treatment for zero discharge.

\section{ACKNOWLEDGEMENT}

The authors would like to thank the DirectorGeneral of MPOB for permission to carry out the research work and for the publication of this article.
The authors also would like to express gratitude to the Director of Engineering and Processing Division of MPOB as well as the staff of Energy and Environment Unit, MPOB for the continuing support in order to complete the research work. Special appreciation to Ronser BioTech Sdn Bhd (Ronser) and Shanghai Jiao Tong University (SJTU) as the technology providers with significant contribution to the project.

\section{REFERENCES}

Ahmad, A L; Ismail, S and Bhatia, S (2003). Water recycling from palm oil mill effluent (POME) using membrane technology. Desalination, 157: 87-95.

Alves, M; Vieira, J M; Pereira, R A; Pereira, M and Mota, M (2001). Effects of lipids and oleic acid on biomass development in anaerobic fixedbed reactors. Part II: Oleic acid toxicity and biodegradability. Water Research, 35: 264-270.

Azmi, N S and Yunos, K F M (2014). Wastewater treatment of palm oil mill effluent (POME) by 
ultrafiltration membrane separation technique coupled with adsorption treatment as pre-treatment. Agriculture and Agricultural Science Procedia, 2: 257264.

Basri, M; Yacob, S; Hassan, M; Shirai, Y; Wakisaka, M; Zakaria, M and Phang, L (2010). Improved biogas production from palm oil mill effluent by a scaled-down anaerobic treatment process. World J. Microbiology and Biotechnology, 26: 505-514.

Chernicharo, C A de L (2007). Anaerobic reactors. Biological Wastewater Treatment Series. IWA Publishing, London. p. 99-100.

Department of Environment (1995). Revised Standard Methods (1985) for Analysis of Rubber and Palm Oil mill Effluents. Second edition. Department of Environment, Malaysia.

Ganidi, N; Tyrrel, S and Cartmell, E (2009). Anaerobic digestion foaming causes - A review. Bioresource Technology, 100: 5546-5554.

Hosseini, S E; Wahid, M A and Aghili, N (2013). The scenario of greenhouse gases reduction in Malaysia. Renewable and Sustainable Energy Reviews, 28: 400409.

Jeganathan, J; Nakhla, G and Bassi, A (2006). Longterm performance of high-rate anaerobic reactors for the treatment of oily wastewater. Environmental Science and Technology, 40: 6466-6472.

Kandiah, S and Batumalai, R (2013). Palm oil clarification using evaporation. J. Oil Palm Res. Vol. 25(2): 235-244.

Kushairi, A; Loh, S K; Azman, I; Hishamuddin, E; Ong-Abdullah, M; Mohd Noor Izzuddin, Z; Razmah, G; Sundram, S and Ahmad Parveez, G K (2018). Oil palm economic performance in Malaysia and R\&D progress in 2017. J. Oil Palm Res. Vol. 30(2): 163-195.

Liew, W L; Kassim, M A; Muda, K; Loh, S K and Affam, A C (2015). Conventional methods and emerging wastewater polishing technologies for palm oil mill effluent treatment: A review. J. Environmental Management, 149: 222-235.
Loh, S; Nasrin, A; Azri, S M; Adela, B N; Muzzammil, $\mathrm{N}$; Jay, T D; Eleanor, R S; Lim, W; Choo, Y and Kaltschmitt, M (2017). First Report on Malaysia's experiences and development in biogas capture and utilization from palm oil mill effluent under the Economic Transformation Programme: Current and future perspectives. Renewable and Sustainable Energy Reviews, 74: 1257-1274.

Loh, S K; Lai, M E; Ngatiman, M; Lim, W S; Choo, Y M; Zhang, Z and Salimon, J (2013). Zero discharge treatment technology of palm oil mill effluent. J. Oil Palm Res. Vol. 25(3): 273-281.

Loh, S K; Lian, L D; Sukiran, M A and Choo, Y M (2011). A biogas trapping facility for handling palm oil mill effluent (POME). MPOB Information Series No. 564: 2 pp.

Ma, A N; Choo, Y M and Yusof, B (1994). Renewable energy from the palm oil industry. J. Oil Palm Res. Vol. 6(2): 136-146.

Ma, A N (1999). Innovations in management of palm oil mill effluent. The Planter, 75 (881): 381-389.

Ma, A N (2000). Environmental management for the oil palm industry. Palm Oil Developments No. 30: 1-10.

Othman, M R; Hassan, M A; Shirai, Y; Baharuddin, A S; Ali, A A M and Idris, J (2014). Treatment of effluents from palm oil mill process to achieve river water quality for reuse as recycled water in a zero emission system. J. Cleaner Production, 67: 58-61.

Tabassum, S; Zhang, Y and Zhang, Z (2015). An integrated method for palm oil mill effluent (POME) treatment for achieving zero liquid discharge - A pilot study. J. Cleaner Production, 95: 148-155.

Rahman, Z A; Hadi, N A; Hawari, Y; Hashim, Z and Tan, D (2013). Zero waste technology for palm oil mills (POMEDfree). MPOB Information Series No. 635: 2 pp.

Yacob, S; Hassan, M A; Shirai, Y; Wakisaka, M and Subash, S (2006). Baseline study of methane emission from anaerobic ponds of palm oil mill effluent treatment. Science of the Total Environment, 366: 187-196. 